\title{
Video Games as Motivators of English Vocabulary Acquisition and Reading
}

\author{
$1^{\text {st }}$ Audrey Ningtyas \\ Linguistics Department, Faculty of \\ Humanities, Universitas Indonesia, \\ Depok, Indonesia \\ audreyy.ns@gmail.com
}

\author{
$2^{\text {nd }}$ Sonya P. Suganda*, \\ Linguistics Department, Faculty of \\ Humanities, Universitas Indonesia, \\ Depok, Indonesia \\ sonya.puspa@gmail.com
}

\begin{abstract}
The current generation of students is keen on playing video games across platforms such as smartphones, personal computers, or other devices. Teachers could take advantage of their enthusiasm for gaming by integrating learning with games played in the classroom or at home. Most students in Indonesia do not consider English as a foreign language important or challenging. There is a marked difference in learning English at school and self-learning: a student must study specific materials by a certain grade at school; however, students can self-learn from discrete types of exposure. Very few students engage in self-learning or know that they must master English. This study examined whether the integration of video games to English classes would motivate students to learn. The experiment focused on enhancing the motivation of students to read English text. Data were collected through a mixed method. Besides collecting pre- and post- tests, the researcher also administered a questionnaire to the students who performed best in the post-test. The t-test calculation performed on the obtained results revealed only a slight increase in the motivation of participating students. The outcomes of the analysis of the questionnaire divulged that the game's visualization helped students who performed best to understand English better and that these learners were incentivized to improve their English by doing what they love.
\end{abstract}

Keywords-motivation, video games, reading, reading comprehension

\section{Introduction}

The need to know English is already widespread in Indonesian society. Besides specialized professional posts and government careers, most undergraduate job profiles require proficiency in English, especially in verbal communication. This need is more palpable because of globalization: a surge of foreigners now visits Indonesia for either tourism or workrelated reasons. Thus, English is needed as a medium of communication with overseas guests. Huda [1] also asserts in her article that university students must master English to read textbooks or papers published internationally. Thus, learners must inculcate the vocabulary range and specific vocabulary required for their own university majors.

Fearing that the spread of English could threaten Indonesia's own national language, Bahasa Indonesia, the government decided to eliminate the subject from the elementary school curriculum and reduced the class time allocated for English in other levels of schooling. This move was perhaps unreasonable because English proficiency is a prominent requirement of Indonesia's rapid globalization. In addition, the Masyarakat Ekonomi Asean (MEA or the ASEAN Economic Community) allows Indonesian companies to recruit foreign workers, especially specialized professionals, from South-East Asian nations. The influx of overseas professionals may be beneficial for Indonesian industry and economy, but the scenario may turn disastrous if Indonesia's own specialized workers cannot compete for such jobs because of language barriers. Tight global competition may result in unemployment for Indonesian specialists, leading to increased poverty and criminality in society.

Indonesians are exposed to English through media such as the Internet, foreign news articles, blogs, YouTube videos, and so on. Nonetheless, formal English learning is also required for Indonesia's future. English is as important for students as any other subject. The knowledge of this language would benefit Indonesia's future performance in international arenas besides being advantageous for individuals in terms of better job opportunities and salary [2]. A representative who has limited English capabilities and cannot adequately reflect Indonesia's interests cannot be tolerated because such representations can damage Indonesia's global relationships.

The researcher's experience of teaching English in school classrooms, as well as a private course, has led to the observation that students generally evince low interest in learning English because they do not think that it is as important as other subjects such as math or physics. They tend to think that the English course is easy because they are accustomed to the use of the language in their daily lives. On the other hand, they know very little about the English materials in their curriculum, even after the syllabus is twice revised by their teacher.

Such low learner interest could also be attributed to deficiencies in English instructors who cannot deliver the assigned materials with the desired proficiency or creativity required for effective language teaching [3]. Teaching is also a specialized profession that is now becoming very competitive. Some of Indonesia's private schools are beginning to recruit English teachers from other South-East Asian countries because they are regarded as more reliable. Indonesia's government responded to this influx of English teachers by imparting training in the teaching of English and certifying those who successfully accomplish the training so Indonesian nationals can prove their updated capability for creative language instruction and compete for available positions. Private courses seeking to teach English, on the other hand, face issues such as student absenteeism for reasons such as tests in other school subjects or homework or the lack of interest in learning English because students think they do not need it at that time of their life. The teacher is still paid in full if students do not attend the private coaching classes, but students lose both in terms of money and opportunity. Such absenteeism validates Sulistiyo's opinion that student motivation is pivotal to effective language learning [4]. 
The low student interest in English also results from a limited vocabulary. Except for a handful of learners who understand that they need to learn English as much as other subjects, most students immediately lose interest when they cannot understand parts of class discussion. A study conducted by John W. Miller, president of Central Connecticut State University in New Britain, CT [5] ranked Indonesia 60 of 61 nations that participated in its survey of the World's Most Literate Nations. Such results are troubling for the nation. Reading is an effective means of improving the vocabulary range of learners; thus students should be encouraged to read assorted English material to amplify their vocabulary.

The integration of hobbies with English reading could be a way to overcome low student motivation to read English texts. Video games are no longer too expensive for most students in Indonesia in this rapidly technological time. Also, most students love to play video games. The English instructor could make use of this gaming hobby and turn it into a more beneficial activity for students. Thus, this study proposed to integrate a video game with classroom instruction to improve the English reading skills of students.

Nation [6] states that to be successful, vocabulary learning needs three aspects to be satisfied. First, observation allows words to be noticed by their colors, shapes, and styles. Second, retrieval is achieved through repeated exposure. Finally, the word must be put to generative use as vocabulary through either image or sound. Video games provide all three opportunities: colorful imagery, the use of different sounds and the fonts, and the repeated use of certain words. Hence, they could certainly be employed to facilitate English learning in students.

Gamification is a term used for programs that aim to educate through the use of game mechanics such as scoring, levels, points, challenges, and so on [7]. The use of such gaming-related features engages players and encourages them to take action, learn, and problem-solve [8]. On the other hand, most video games only serve to entertain. Most gamification programs are tied to particular learning objectives and it is difficult to find specific programs for study unless they are developed by researchers themselves. The video game used for this study is different from gamification and may be categorized purely as a video game. At best, the game could be classified as edutainment: although certain aspects relate the game to education, its entertainment aspects [9] such as the gameplay do not focus unduly on the study material.

This study was conducted to obtain empirical evidence of the motivational impact of video games vis-à-vis reading in English and to ascertain the aspects of gaming that most elicit the interest of English learners. Video games are generally considered useless in Indonesia because they only serve the purpose of entertainment. In fact, Pellegrini [10] claims that a game-based environment can encourage learning and induce behavioral change. For example, a video game that requires a strategy to win can shape can make a player think like a strategist and could thus influence the person's future. The current study attends specifically to the act of motivating students to read and improve their reading skills.

\section{Method}

This research project was conducted via a mixed methodology to gather deeper and meaningful data and deduce clear results so future researchers may improve on the outcomes of this study. The mixed-method investigation included a pre- and post-test experiment test, the administration of a questionnaire, and the researcher's observations. Each data collection technique was applied to the answering of the stated research questions. The pre- and post-test helped to determine whether video games significantly improved the reading abilities of students; the questionnaire and observations facilitated the compilation of information about the motivation levels of the students and enabled the researcher to correlate this assessed motivation with the pre- and post-test results attained by students.

The researcher specifically selected a class that exhibited below-average scores in English. Such low performance implied that the English proficiency of this class needed improvement and that the students required to learn more effectively. The researcher also selected the eighth grade of junior high school because, at this stage, students are already adapted to the school environment, and more importantly, they do not need to focus on forthcoming national schoolleaving examinations. The researcher endeavored to make the classes entertaining and engaging for the students and to create an "out-of-school" atmosphere to mitigate any loss of concentration arising from the confusion student may feel by wondering what they were being taught through the game experience. In total, 30 students participated in the experiment up to its final stage. A control class at the same level of proficiency was included for comparative analysis. The traditional lecture-style pedagogic method using markers and whiteboards was applied in the control classroom. Identical study materials were used for the control and the experimental classes.

The study materials for the class pertained to narrative texts. The syllabus for this topic required students to achieve the objective of understanding the definition, purpose, and structure of a narrative text. The researcher then selected a video game with a narrative base of a story being unfolded. The video game is basically a visual novel in which the player must read the dialogues uttered by characters and select the best options to proceed further in the game and achieve an advantageous end score. The game included the phases of introduction, conflict, and resolution. The researcher hoped that the playing of this video game would facilitate superior understanding and memory in students and would also enhance learning motivation and reading skills. Students were asked to bring their laptops to the class. However, all students were not allowed to bring their laptops to the school, thus students were assigned laptops in pairs: two students to every laptop. Then, the researcher installed the video game and ensured that it was functional in each laptop.

The video game used for this study is named Suikoden II. It was published in 1999 in North America and was released in Europe in 2000 on the Playstation platform. At that time, the game was quite popular. The story was different from most of the games published in that year. The researcher picked this game because it includes a manual to facilitate gameplay and is more accessible than games available via mobile phone apps. The file size is reasonably small and it does not take up much laptop disc space. Unlike most modern games, this 
game also does not include graphic violence, and it is full of text. It thus suits the purpose of this research.

The edutainment framework of the present study required subjects to read the texts included in the game. If they did not understand the meaning of a word or phrase, students could refer to the dictionary. The researcher hoped that the experience of checking meanings would habituate students to scan dictionaries to search for meaning so they would also apply it to other language learning activities. It was presumed that vocabulary acquisition would definitely occur if students were repeatedly exposed to certain words by the game. Thus, the vocabulary range of the learners could be expanded purely through the gaming experience.

To begin the experiment, the researcher explained the study material to the students along with an example of the narrative text. The participating students were also taught to play the game and practiced it for a while before taking the pre-test, which was administered only after all the students demonstrated that they could play the game on their own. The pre-test comprised 10 short narrative texts with 5 questions asked on each text. The questions were assigned their own rubric as follows.

\begin{tabular}{|c|c|c|}
\hline Indicator & Questions Number & $\begin{array}{c}\text { Total } \\
\text { Questions } \\
\end{array}$ \\
\hline \multirow{3}{*}{$\begin{array}{l}\text { 1. Determining the } \\
\text { schematic structure: } \\
\text { a. Orientation: Characters, } \\
\text { setting, plot }\end{array}$} & $\begin{array}{c}\text { Characters: } 1,35,37, \\
42,43\end{array}$ & 5 \\
\hline & $\begin{array}{c}\text { Setting: } 2,14,34,39 \text {, } \\
46\end{array}$ & 5 \\
\hline & Plot: 6. 20.23. 27. 28 & 5 \\
\hline b. Complication & $11,16,31,45,59$ & 5 \\
\hline c. Story sequence & $5,8,24,33,38$ & 5 \\
\hline $\begin{array}{l}\text { d. Resolution: moral of the } \\
\text { story }\end{array}$ & $4,10,22,29,32$ & 5 \\
\hline \multirow{3}{*}{$\begin{array}{l}\text { 2. Ability to make inferences } \\
\text { of events in the story and } \\
\text { finding the synonym and } \\
\text { antonym }\end{array}$} & $\begin{array}{c}\text { Inference: } 9,12,18, \\
25,48\end{array}$ & 5 \\
\hline & $\begin{array}{c}\text { Synonym: } 3,7,13, \\
17,21\end{array}$ & 5 \\
\hline & $\begin{array}{c}\text { Antonym: } 26,30,40, \\
41,44\end{array}$ & 5 \\
\hline \multirow[t]{2}{*}{$\begin{array}{l}\text { 3. Determining the story } \\
\text { organization }\end{array}$} & $15,19,36,47,49$ & 5 \\
\hline & Total Questions & 50 \\
\hline
\end{tabular}

Table 1. Rubric for Pre- and Post-tests

The table above illustrates the rubric for the questions pertaining to reading comprehension. Students were required to understand each point of the criteria to increase their reading skills and vocabulary. A validity and reliability test were conducted before the actual testing was accomplished.

The experimental treatment lasted 4 weeks with 2 sessions per week. In each session, the researcher observed the behavior evinced by the subjects toward the use of the video game. After 4 weeks, the participants took a post- test to determine their final scores, and the differences between the pre- and post-test scores were computed. The students who scored high in their tests were administered questionnaires regarding their motivation to read in the following next week.

The t-test was used for the pre and post- test scores because the number of subjects was small. After the high-scoring students had filled in their questionnaires, the researcher synthesized the test-score evaluations, the data obtained from the questionnaires, and the observations noted during the sessions to arrive at a conclusion. An interview component should also have been included in the ideal experimental scenario. Unfortunately, the mid-semester examinations were imminent, and there was no time available for the conduction of interviews.

By the video game experiment was conducted, it was hypothesized that the gaming experience would enhance the reading skills and vocabulary range of the participating students. Also, they would become more aware of media they could use on their own for language learning. The hypothesis stemmed from the researcher's own experience of applying the stated methodology to gradually improve her English skills. The present study was conducted to determine whether such success could be generalized or applied to others.

\section{Results and Discussion}

Before using the research instrument, the researcher tested the instrument on another class from the same school and measured the validity and reliability of the items through a program called Anatest, developed by Karnoto and Yudi Wibisono. The test confirmed that 63 of the 70 items were valid. These items were categorized to form the rubric for the test questions. Language research mandates a 5\% degree of significance 0.16 to confirm reliability: the tests for this study evinced a score of more than 0.16 .

The pre- and post- tests should also be normally distributed and homogenous to avoid biased results from subjects of both classes. The Shapiro-Wilk SPSS was utilized to calculate data normality and descriptive statistics were used to calculate data homogeneity. Both tests evidenced the normal distribution and homogeneity of the pre- and post- test.

Furthermore, the t-test formula was used to compare the scores between the experimental and control classes so that the two previously posited research questions could be answered. The computed data evidenced only a slight change in the reading skills of students of the two groups. Some students, however, demonstrated an impressive gain in their scores. The detailed scores are presented in the table below.

\begin{tabular}{ccccccc}
\hline No. & $\mathbf{X}$ & $\mathbf{Y}$ & $\mathbf{X}$ & $\mathbf{y}$ & $\mathbf{X}^{\mathbf{2}}$ & $\mathbf{y}^{\mathbf{2}}$ \\
\hline 1 & 4 & 4 & -7.4 & -5.53 & 54.76 & 30.5809 \\
\hline 2 & 8 & 16 & -3.4 & 6.47 & 11.56 & 41.8609 \\
\hline 3 & 14 & 2 & 2.6 & -7.53 & 6.76 & 56.7009 \\
\hline 4 & 4 & 4 & -7.4 & -5.53 & 54.76 & 30.5809 \\
\hline 5 & 14 & 12 & 2.6 & 2.47 & 6.76 & 6.1009 \\
\hline 6 & 14 & 2 & 2.6 & -7.53 & 6.76 & 56.7009 \\
\hline 7 & 8 & 20 & -3.4 & 10.47 & 11.56 & 109.6209 \\
\hline 8 & 2 & 14 & -9.4 & 4.47 & 88.36 & 19.9809 \\
\hline 9 & 20 & 10 & 8.6 & 0.47 & 73.96 & 0.2209 \\
\hline 10 & 14 & 16 & 2.6 & 6.47 & 6.76 & 41.8609 \\
\hline 11 & 10 & 20 & -1.4 & 10.47 & 1.96 & 109.6209 \\
\hline 12 & 8 & 8 & -3.4 & -1.53 & 11.56 & 2.3409 \\
\hline 13 & 12 & -6 & 0.6 & -15.53 & 0.36 & 241.1809 \\
\hline 14 & 16 & 28 & 4.6 & 18.47 & 21.16 & 341.1409 \\
\hline 15 & 12 & 10 & 0.6 & 0.47 & 0.36 & 0.2209 \\
\hline 16 & 18 & 8 & 6.6 & -1.53 & 43.56 & 2.3409 \\
\hline 17 & 22 & 2 & 10.6 & -7.53 & 112.36 & 56.7009 \\
\hline 18 & 2 & 24 & -9.4 & 14.47 & 88.36 & 209.3809 \\
\hline 19 & 8 & 4 & -3.4 & -5.53 & 11.56 & 30.5809 \\
\hline 20 & 4 & -2 & -7.4 & -11.53 & 54.76 & 132.9409 \\
\hline & & & & & &
\end{tabular}




\begin{tabular}{ccccccc}
\hline No. & $\mathbf{X}$ & $\mathbf{Y}$ & $\mathbf{X}$ & $\mathbf{y}$ & $\mathbf{x}^{\mathbf{2}}$ & $\mathbf{y}^{\mathbf{2}}$ \\
\hline 21 & 10 & 6 & -1.4 & -3.53 & 1.96 & 12.4609 \\
\hline 22 & 12 & 8 & 0.6 & -1.53 & 0.36 & 2.3409 \\
\hline 23 & 14 & 12 & 2.6 & 2.47 & 6.76 & 6.1009 \\
\hline 24 & 16 & 6 & 4.6 & -3.53 & 21.16 & 12.4609 \\
\hline 25 & 8 & 12 & -3.4 & 2.47 & 11.56 & 6.1009 \\
\hline 26 & 16 & 4 & 4.6 & -5.53 & 21.16 & 30.5809 \\
\hline 27 & 22 & 18 & 10.6 & 8.47 & 112.36 & 71.7409 \\
\hline 28 & 10 & 6 & -1.4 & -3.53 & 1.96 & 12.4609 \\
\hline 29 & 12 & 10 & 0.6 & 0.47 & 0.36 & 0.2209 \\
\hline 30 & 8 & 8 & -3.4 & -1.53 & 11.56 & 2.3409 \\
\hline SUM & $\mathbf{3 4 2}$ & $\mathbf{2 8 6}$ & & & $\mathbf{8 5 7 . 2}$ & $\mathbf{1 6 7 7 . 4 6 7}$ \\
\hline AVG & $\mathbf{1 1 . 4}$ & $\mathbf{9 . 5 3}$ & & & $\mathbf{2 8 . 5 7 3 3 3}$ & $\mathbf{5 5 . 9 1 5 5 7}$ \\
\hline
\end{tabular}

Table 2. Statistical Calculation of Gained Scores of the Experimental and Control Classes

As the above table demonstrates, the experimental class gained a total of 342 points in comparison the aggregate of 286 gained by the controlled class. Thus, the experimental class did earn a higher score than the controlled class. Once the gained score was calculated, the number was placed into the $\mathrm{t}$-test formula as follows:

1. Determining mean of variable $\mathrm{X}$ (Experiment Class):

$$
\mathrm{M} \_\mathrm{x}=\left(\sum \text { wi: } \mathrm{fx}\right) / \mathrm{N} \_\mathrm{x}=342 / 30=11.4
$$

2. Determining mean of variable $\mathrm{Y}$ (Control Class):

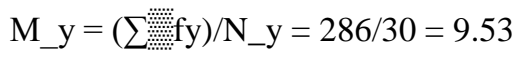

3. Determining standard deviation of variable $\mathrm{X}$ :

$=\sqrt{ } 28.57=5.34$

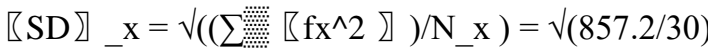

4. Determining standard deviation of variable $\mathrm{Y}: \mathrm{e}$

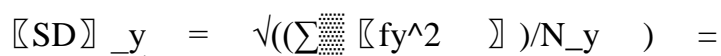

$\sqrt{ }(1677.467 / 30)=\sqrt{ } 55.91=7.47$

5. Determining standard error of mean variable $X$ :

$$
\text { 『SE】_(M_x })=\llbracket \mathrm{SD}{ }_{-} \mathrm{x} / \sqrt{ }(\mathrm{N}-1)=5.34 / \sqrt{ }(30-1)
$$
$=5.34 / 5.38=0.99$

6. Determining standard error of mean variable $\mathrm{Y}$ :

$$
\text { 『SE } \_\left(M \_y\right)=\llbracket S D \nabla \_y / \sqrt{ }(N-1)=7.47 / \sqrt{ }(30-1)
$$

$=7.47 / 5.38=1.38$

7. Determining standard error of different mean of variable $\mathrm{x}$ and mean of variable $\mathrm{Y}$ :

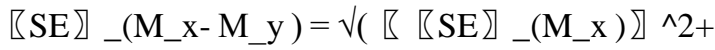

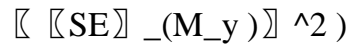

$$
\begin{aligned}
\quad & =\sqrt{ }(\llbracket 0.99 \rrbracket \wedge(2)+\llbracket 1.38 \rrbracket \wedge 2) \\
= & \sqrt{ }(0.981+1.9044) \\
= & \sqrt{ } 2.8854 \\
= & 1.69
\end{aligned}
$$

8. Statistical t-test formula:

【t_o】_(=(M_x-M_y $) /$ 【SE】_(M_(x-) M_y $)=(11.4$ $9.53) / 1.69=1.87 / 1.69=1.10$ )
9. Determining t_table in significance level 0.05 , with $\mathrm{df}$ (degree of freedom)

$\mathrm{df}=(\mathrm{Nx}+\mathrm{Ny})-2=(30+30)-2=58$

The above calculation evinces the df value of 58 and the degree of significance value of 0.05 (t-table 1.67), and the tvalue of 1.10 . Thus, the $t$-test calculation evidences a $t$-value lower than the t-table. Thus, the use of the video game methodology did not improve the reading skills of students as expected. Perhaps the treatment did not validate the hypothesis because the preparation of the experiment required a longer expense of time and needed to be explained in detail to the subjects. Also, the researcher observed that some of the students could not operate the laptop as explained, which made their progress a little slower than others who were better able to operate their laptops. The subjects needed to be accorded more time to adapt to this new learning style and new technology. This difficulty can be overcome if the subjects could bring their own smartphones

\begin{tabular}{|c|c|c|c|c|c|c|}
\hline No & Statements & $\begin{array}{c}\text { Strongl } \\
\mathbf{y} \\
\text { Disagr } \\
\text { ee }\end{array}$ & $\begin{array}{c}\text { Disagr } \\
\text { ee }\end{array}$ & $\begin{array}{c}\text { Neutr } \\
\text { al }\end{array}$ & $\begin{array}{c}\text { Agre } \\
\text { e }\end{array}$ & $\begin{array}{c}\text { Strongl } \\
\mathbf{y} \\
\text { Agree }\end{array}$ \\
\hline 1 & $\begin{array}{c}\text { I'm so } \\
\text { motivated } \\
\text { when I try to } \\
\text { learn via video } \\
\text { games. } \\
\end{array}$ & - & - & 4 & 4 & 3 \\
\hline 2 & $\begin{array}{l}\text { When I face a } \\
\text { word that I } \\
\text { don't know, } \\
\text { I'm so } \\
\text { motivated to } \\
\text { learn it. }\end{array}$ & - & 1 & 1 & 6 & 3 \\
\hline 3 & $\begin{array}{c}\text { Learning } \\
\text { vocabulary via } \\
\text { video games is } \\
\text { stressful. }\end{array}$ & 3 & 3 & 2 & 1 & 2 \\
\hline 4 & $\begin{array}{l}\text { Video games } \\
\text { make } \\
\text { vocabulary } \\
\text { learning more } \\
\text { boring. }\end{array}$ & 3 & 2 & 4 & 1 & 1 \\
\hline 5 & $\begin{array}{l}\text { Facing new } \\
\text { words } \\
\text { incidentally } \\
\text { helped me to } \\
\text { grasp them } \\
\text { better. }\end{array}$ & - & 1 & 1 & 6 & 3 \\
\hline 6 & $\begin{array}{c}\text { The virtual } \\
\text { world of the } \\
\text { game helped } \\
\text { me to }\end{array}$ & - & - & - & 7 & 4 \\
\hline
\end{tabular}
to the class. This move would make it easier and faster for them to play the game on their smartphones and could change the outcomes of the gained scores.

On the other hand, the questionnaire revealed a contradictory result, especially for the subjects who attained impressive scores. The questionnaire analysis divulged a significant increase in the motivation and interest of subjects who achieved high scores in their reading in English through the video game. 


\begin{tabular}{|c|c|c|c|c|c|c|}
\hline & $\begin{array}{l}\text { understand the } \\
\text { meaning of } \\
\text { new words. }\end{array}$ & & & & & \\
\hline 7 & $\begin{array}{l}\text { The meaning of } \\
\text { the words } \\
\text { became crystal } \\
\text { clear through } \\
\text { the support } \\
\text { obtained from } \\
\text { the virtual } \\
\text { world of the } \\
\text { game. }\end{array}$ & - & - & 6 & 3 & 2 \\
\hline 8 & $\begin{array}{l}\text { When gaming, } \\
\text { I felt like I was } \\
\text { in an English- } \\
\text { speaking } \\
\text { country. }\end{array}$ & - & - & 3 & 3 & 5 \\
\hline 9 & $\begin{array}{l}\text { I learned new } \\
\text { words visually. }\end{array}$ & - & 1 & 1 & 7 & 2 \\
\hline 10 & $\begin{array}{l}\text { When I recall } \\
\text { words I learned } \\
\text { via the video } \\
\text { game, I } \\
\text { remember their } \\
\text { images too. }\end{array}$ & 1 & 2 & 2 & 3 & 3 \\
\hline 11 & $\begin{array}{c}\text { Having fun } \\
\text { didn't reduce } \\
\text { my learning. }\end{array}$ & - & - & 2 & 4 & 5 \\
\hline 12 & $\begin{array}{l}\text { Having fun } \\
\text { motivated me } \\
\text { to continue my } \\
\text { learning for } \\
\text { long hours. }\end{array}$ & - & - & 1 & 5 & 5 \\
\hline 13 & $\begin{array}{l}\text { Sound bites, } \\
\text { pictures, and } \\
\text { graphics helped } \\
\text { me to better } \\
\text { understand the } \\
\text { meanings of } \\
\text { words. }\end{array}$ & - & - & 2 & 4 & 5 \\
\hline 14 & $\begin{array}{l}\text { Video games } \\
\text { provide } \\
\text { opportunities } \\
\text { for the } \\
\text { intentional } \\
\text { learning of } \\
\text { vocabulary. }\end{array}$ & - & - & 5 & 1 & 5 \\
\hline 15 & $\begin{array}{l}\text { Video games } \\
\text { make learning } \\
\text { engaging. }\end{array}$ & - & - & 2 & 4 & 5 \\
\hline 16 & $\begin{array}{l}\text { I don't feel the } \\
\text { pressure of } \\
\text { learning when I } \\
\text { learn via video } \\
\text { games. }\end{array}$ & 1 & 3 & 4 & 2 & 1 \\
\hline 17 & $\begin{array}{l}\text { I don't get } \\
\text { nervous when I } \\
\text { don't know the } \\
\text { meaning of a } \\
\text { word in a } \\
\text { video. }\end{array}$ & - & 3 & 2 & 2 & 4 \\
\hline 18 & $\begin{array}{l}\text { I think video } \\
\text { games make } \\
\text { language } \\
\text { learning more } \\
\text { interesting. }\end{array}$ & - & - & 1 & - & 10 \\
\hline
\end{tabular}

Table 3. Analysis Results of the Questionnaire on Motivation
The above table leads to the conclusion that most of the subjects who attained impressive scores in their tests enjoyed learning through the video game methodology. Some answers were neutral, but other statements proved that the use of video games for learning did motivate students to learn.

These answers to the questionnaire support Nation's [6] postulation of the three characteristics of vocabulary acquisition. The medium of the video game can enhance reading skills, especially in English, because of their visualization and their entertainment environment that helps to immerse students into the game characters. Perhaps many subjects failed to gain impressive scores primarily because they did not enjoy playing video games. These subjects may never before have played such a game, and may thus have sensed confusion or could have been otherwise disturbed during the experimental treatment.

Also, subjects could not memorize better as they played the video game primarily because of the paucity of time: the treatment was accomplished in only 4 weeks. The limited repetitive exposure may not have been adequate for subjects who evince different spans of memorizing skills. Moreover, subjects expressed mixed feelings about whether they were pressured while playing the video game. The treatment was conducted in a classroom with limited laptops and restricted time to play freely. The results could have been different if the subjects could bring their own smartphones to the class. Unfortunately, the school has strict rules about not allowing subjects to carry their phones to the classroom as it interferes with the teaching and learning process.

Future researchers should specifically attend to the preparation and the duration of this type of research. A study that involves media learning needs participants to acquire a deep understanding of the media usage and manuals to avoid the issues that were observed in this research endeavor. A longer duration is also recommended for such experimental research initiatives and is estimated to yield better results because the accuracy of the evidence obtained from such short studies cannot be guaranteed. Further, prospective researchers should consider the inclusion of subjects with different learning styles because all students cannot be expected to be visual or auditory in their learning styles.

\section{Conclusion}

Amplifying student motivation for language learning is a challenging task. Teachers should try to explore the interest levels of their students and should take their opinions on board as they maintain their role in facilitating learning. The introduction of a familiar pastime medium as a learning source may help to motivate students to learn. Students who feel that they cannot understand a subject tend to simply give up stop caring. By being creative and knowledgeable, teachers can solve this problem. The integration of video games with language learning is an example of pedagogic creativity that utilizes the student group's natural affinity toward gaming technology. The proposed methodology is different from other, more traditional, teaching and learning processes, and thus intrigues students as they become aware that they can learn from their hobbies. This study made students aware of such a possibility vis-à-vis the acquisition of English language proficiency. The students who participated in the experiment conducted for this study are thus more open to their learning 
styles, and more aware of their possibilities should they desire to learn something on their own.

Research projects regarding the use of video games in the classroom are still rare in Indonesia. The present study could serve as a reference for the discovery of better access to video games as learning media and could spur other proposed methods of using video games in the classroom environment or as an aspect of the teaching and learning process. It is hoped that future researchers will utilize the design and outcomes of the current investigation as an opportunity to initiate the employment of video game technology to the amelioration of English language learning programs.

\section{Acknowledgment}

This work is supported by Universitas Indonesia's Research Grant (PITMA B 2019) managed by DRPM UI/Indonesian Ministry of Research, Technology, and Higher Education's Research Grant (PDUPT 2019) managed by DRPM UI. The first author would like to express her gratitude toward Dr. Sonya P. Suganda, M.A. for her unrelenting patience to guide and supervise this article.

\section{References}

[1] Huda, N. (2016). A national strategy in achieving English communicative ability: Globalisation perspectives. Jurnal Ilmu Pendidikan, 4

[2] Rini, J. E. (2014). English in Indonesia. Beyond Words, 2(2), 19-39.

[3] Bradford, A. (2007). Motivational orientations in under-researched FLL contexts: Findings from Indonesia. RELC Journal, 38(3), 302323. doi:10.1177/0033688207085849

[4] Sulistiyo, U. (2009). Learning English in an Indonesian university: A study of learners' preferred activities. La Trobe University.

[5] Miller, J. W., \& McKenna, M. C. (2016). World literacy: How countries rank and why it matters. New York, NY: Routledge.

[6] Nation, I. S. P. (2001). Learning Vocabulary in Another Language. Cambridge: Cambridge University Press.

[7] Deterding, S., Sicart, M., Nacke, L., O’Hara, K., \& Dixon, D. (2011) Gamification: Using game design elements in non-gaming contexts. In Proceedings of CHI Extended Abstracts (pp. 2425-2428). New York, NY: Association for Computing Machinery. doi: $10.1145 / 1979742.1979575$

[8] Kapp, K. M. (2012). The gamification of learning and instruction: game-based methods and strategies for training and education. Hoboken, NJ: John Wiley \& Sons.

[9] Anikina, O. V., \& Yakimenko, E. V. (2015). Edutainment as a modern technology of education. Procedia-Social and Behavioral Sciences, 166, 475-479. doi:10.1016/j.sbspro.2014.12.558

[10] Pellegrini, A. D. (2009). The role of play in human development. New York, NY: Oxford University Press. 